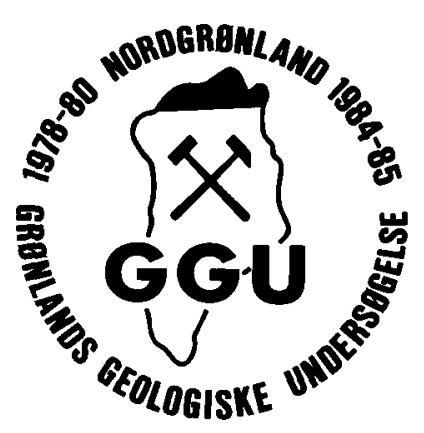

\title{
Cambrian - Lower Silurian slope and basin stratigraphy between northern Nyeboe Land and western Amundsen Land, North Greenland
}

\author{
A. K. Higgins and N. J. Soper
}

Brief description is given of the Cambrian - Lower Silurian sequence in northern parts of central and western North Greenland, which underlies the turbidites of the Silurian Peary Land Group. Lower parts of the sequence pertain to the southern shelf, and upper parts to the northern slope or basin.

A. K. H., Grønlands Geologiske Unders $\emptyset$ gelse, Øster Voldgade 10, DK-1350 Copenhagen K, Denmark.

N. J. S., Department of Geology, University of Sheffield, Mappin Street, Sheffield $S 13 J D, U$. K.

In the course of structural studies (see Soper \& Higgins, 1985), observations were made on the stratigraphical units involved in the deformation over the region between northern Nyeboe Land and western Amundsen Land (fig. 1). Some of these units pertain to the southern shelf (e.g. sub-Portfjeld Formation clastics, Portfjeld Formation carbonates, Buen Formation) and others to the northern slope or trough (e.g. Polkorridoren Group, Vølvedal Group, Amundsen Land Group, and unnamed equivalents).

\section{Sub-Portfjeld Formation sequences}

The lowest rock units encountered were sequences of sandstones and shales beneath the Portfjeld Formation east of J. P. Koch Fjord, in Navarana Fjord and in northern Wulff Land.

East of central J. P. Koch Fjord a $65 \mathrm{~m}$ sequence was measured comprising dark shale, siltstone, thin sandy dolomite, and several massive coarse sandstone beds showing channelling and trough cross-bedding. The sequence beneath the Portfjeld Formation in the core of the anticline in Navarana Fjord is probably similar, but only massive units of rusty weathering sandstone are exposed.

The thickest sequence known, probably greater than $600 \mathrm{~m}$, is in northern Wulff Land. Here F. Surlyk and J. M. Hurst measured a detailed section in 1979, and in 1984 F. G. Christensen (personal communication, 1984) also logged a $400 \mathrm{~m}$ sequence of silty shale, black limestone, dolomitic sandstone and coarse sandstone. These sediments are reported to be distinctly shallow water deposits. This sequence has been compared by Dawes \& Peel (1984) 


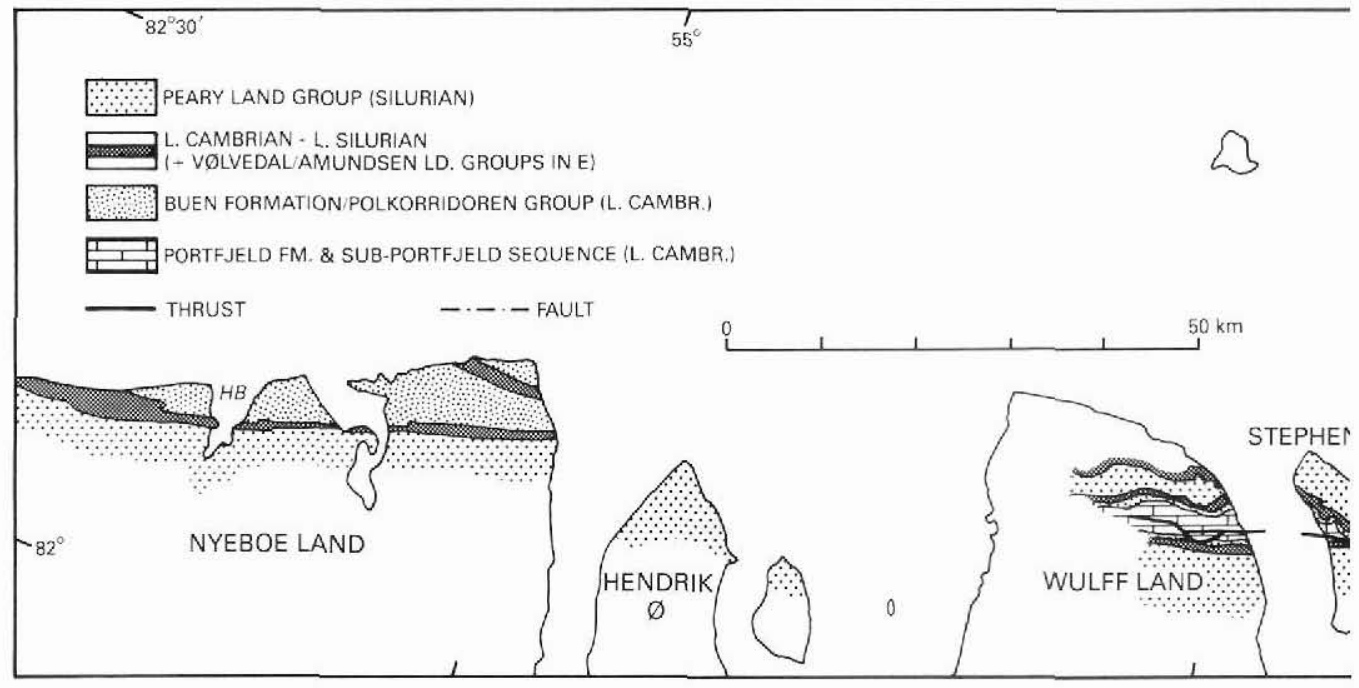

Fig. 1. Geological map showing distribution of some of the Lower Cambrian - Lower Silurian lithological units between Nyeboe Land and Kap Holger Danske. BS: Brainard Sund; B: Kap Bopa; H: Kap Holger Danske; HB: Hand Bugt.

to the Kennedy Channel Formation of eastern Ellesmere Island, the upper part of which is now known to be Lower Cambrian (Robson, 1983).

In its development the sub-Portfjeld sequence in Wulff Land resembles that of the Skagen Group of north-east Peary Land (Friderichsen et al., 1982) which underlies the Paradisfjeld Group; the latter is the deep-water equivalent of the Portfjeld Formation (Surlyk et al., 1980).

\section{Portfjeld Formation}

The presence of a conspicuous dolomite unit in northern Wulff Land has been known since 1966 (Dawes, 1976). Following studies in 1979 the dolomites were referred by Peel (1982) to the Portfjeld Formation. The sequence is more than $325 \mathrm{~m}$ thick and includes several stromatolite levels.

In 1984 further outcrops of Portfjeld Formation dolomites were encountered in Navarana Fjord and over a broad area east of central J. P. Koch Fjord. These outcrops lie approximately on strike with the Wulff Land outcrops to the west and exposures $200 \mathrm{~km}$ to the east in the G. B. Schley Fjord region of eastern Peary Land (Christie \& Ineson, 1979). These are the northernmost exposures of the Portfjeld Formation, the equivalent deposits farther north being the basinal carbonates of the Paradisfjeld Group (Friderichsen et al., 1982; Friderichsen \& Bengaard, 1985).

The sequence in Navarana Fjord is about $260 \mathrm{~m}$ thick. It begins with a $35 \mathrm{~m}$ dark grey unit of carbonates and thin-bedded silicified shales. The bulk of the sequence is formed by a pale grey or yellow-grey weathering unit of massive, crag-forming dolomites $150 \mathrm{~m}$ thick; it in- 


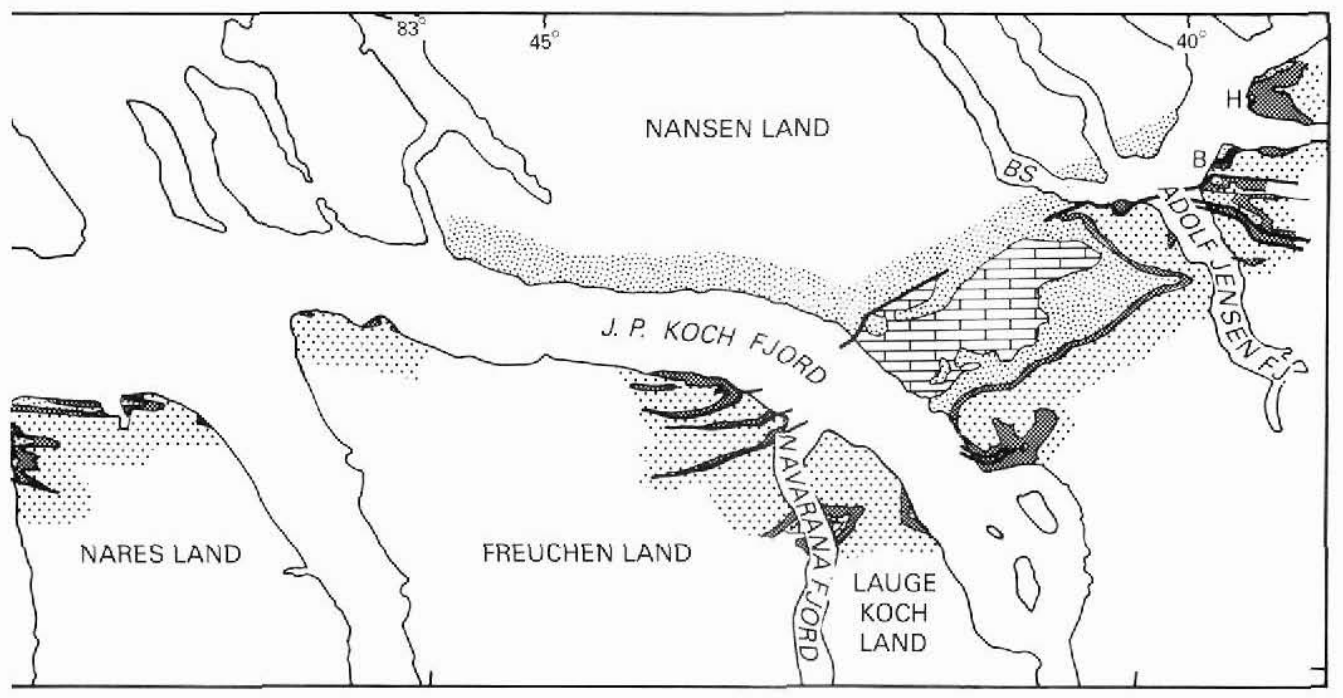

cludes many levels of resedimented, fine-grained breccias and pisolitic grainstones with parallel and cross-lamination, and many slumped beds. The upper $75 \mathrm{~m}$ is thinner-bedded, with an increasing proportion of isolated quartz grains upwards, and terminates with a $1 \mathrm{~m}$ bed of conspicuously well rounded quartz granules.

The broad area of Portfjeld Formation exposed in an anticlinal structure east of inner J. P. Koch Fjord is composed of a dolomite sequence at least $500 \mathrm{~m}$ thick. It comprises dark-grey, orange-grey and grey-white dolomites with conspicuous stromatolite levels locally.

\section{Buen Formation / Polkorridoren Group}

The clastic sediments overlying the Portfjeld Formation are deltaic to marine sandstones and shales of the Buen Formation (J. D. Bryant and J. S. Peel, personal communication, 1984), whereas the thicker basin equivalents are turbiditic sandstones and shales of the Polkorridoren Group (Friderichsen et al., 1982; Surlyk \& Hurst, 1984). The Buen Formation was known to be exposed in northern Wulff Land (Peel, 1982), and is now also known on Stephenson $\varnothing$, north-west Nares Land and in Navarana Fjord (fig. 1). East of inner J. P. Koch Fjord a northward transition can be traced between rock units typical of the Buen Formation and thicker, more basinal, siliciclastics of the Polkorridoren Group. The dark shales and sandstones of northern Nyeboe Land compared by Dawes (1982) to either the turbidites of the Vølvedal Group or the Polkorridoren Group are now known to correspond to the latter; the Vølvedal Group turbiditic sandstones do not occur in the outcrops west of Kap Holger Danske, the west point of Amundsen Land (see below).

In Navarana Fjord the Buen Formation is about $230 \mathrm{~m}$ thick. The lower $80 \mathrm{~m}$ includes silty shales at the base, a $5 \mathrm{~m}$ unit of red, micaceous sandstone with a central slump bed, and a $60 \mathrm{~m}$ unit of siltstones with a variable proportion of sandstone beds in the lower part and a characteristically bioturbated upper part. The upper $c .150 \mathrm{~m}$ of the sequence comprises brown weathering silty shales, terminating at an orange-yellow mineralised marker bed; this thin, 
pyrite-rich, dolomite bed forms the basal unit of the overlying carbonate sequence, but discolouration often extends downwards into the Buen Formation shales. The upper few metres of the Buen Formation contain fragmentary Lower Cambrian fossils (J. S. Peel, personal communication, 1984).

East of J. P. Koch Fjord, the Buen Formation sequence thickens northwards across the major anticline of Portfjeld Formation carbonates. On the south side of the anticline two thick units of trough cross-bedded and channelled quartzites occur in the lower part. On the north side of the anticline the sequence consists of dark-weathering turbiditic sandstones and shales of Polkorridoren Group type. Coloured green-grey and purple shales, typical of the Frigg Fjord mudstone (the uppermost division of the Polkorridoren Group - Friderichsen et al., 1982), are a conspicuous feature of both the Buen Formation and Polkorridoren Group east of J. P. Koch Fjord. Similar coloured shales are also recorded in the Buen Formation of Navarana Fjord and north-west Nares Land.

\section{Cambrian - Lower Silurian starved basin sequence}

Between northern Nyeboe Land and Kap Bopa, an east-west distance of about $250 \mathrm{~km}$, the late Lower Cambrian to earliest Silurian is represented by a starved-basin carbonate and chert sequence of the same rock types and age as the Hazen Formation of Ellesmere Island (Trettin, 1971; Trettin et al., 1979). The sequence overlies Buen Formation shales, and is conformably overlain by turbidites of the Peary Land Group. North-east of Kap Bopa there is a rapid facies change to the turbiditic sandstones, siltstones and cherts of the Vølvedal Group, and cherts, shales and thin-bedded turbiditic sandstones of the Amundsen Land Group (Friderichsen et al., '1982; Surlyk \& Hurst, 1984). The base of the starved basin sequence in some areas shows close similarities with the equivalent shelf sequence to the south (J. S. Peel, personal communication, 1984). Formal description and subdivision of the sequence awaits completion of field work in 1985.

Thirteen complete sections were measured through this sequence in 1984 between northern Nyeboe Land and Kap Holger Danske, together with several incomplete sections, and logs of the top and base in greater detail. The complete sections show a range in thickness from $58 \mathrm{~m}$ to $475 \mathrm{~m}$, with most in the range $350-450 \mathrm{~m}$. In most sections a division into four units can be made (fig. 2).

The lowest carbonate unit is a sequence of rubbly weathering, often nodular, dark limestones and dolomites with shaly partings, usually including a prominent carbonate breccia/ conglomerate bed. A mineralised bed is often present at the base. Samples from the base of this unit collected in northern Nyeboe Land in 1966 by P. R. Dawes have yielded a late Early Cambrian fauna (Peel, 1974, 1979; Dawes \& Peel, 1984; Peel \& Larsen, 1984). Samples collected by us from several localities have yielded a comparable fauna including Hadimopanella apicata, brachiopod and trilobite fragments, and Obruchevella sp. (N. H. Larsen, personal communication, 1985). The basal few metres of the sequence on Stephenson $\emptyset$ yielded an olenellid trilobite (J. S. Peel, personal communication, 1984).

The succeeding chert and shale unit comprises a variable thickness of black cherts, cherty shales and deeply weathered paper shales, usually together with one or two thin beds of grey quartzite. No fossils have been recorded.

The dolomite unit, the thickest of the four units, can usually be traced as a conspicuous yellow weathering sequence. The principal lithology is thinly bedded, very fine grained dol- 


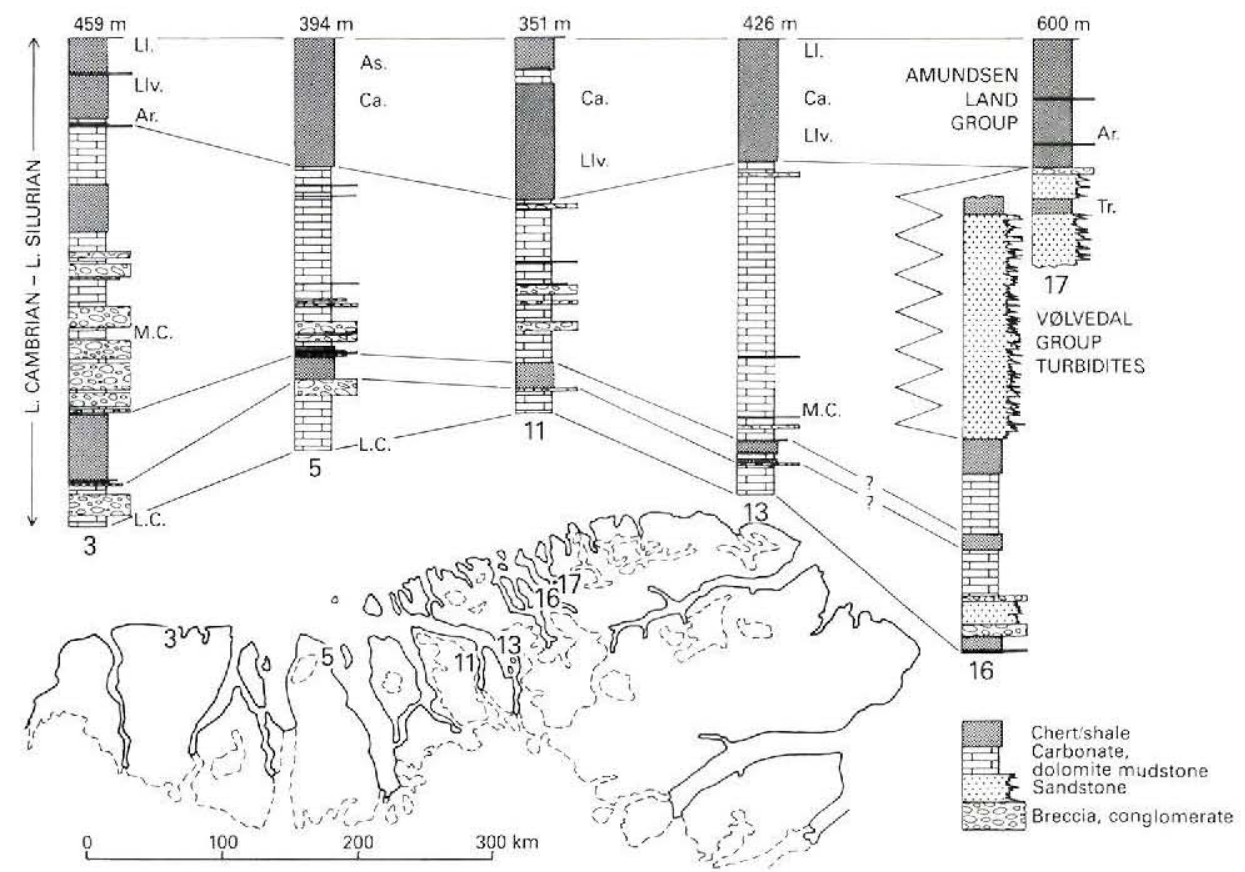

Fig. 2. Simplified measured sections through the Lower Cambrian - Lower Silurian starved basin sequence showing four-part division and interdigitation with Vølvedal Group turbidites. Section 3: west side Hand Bugt, Nyeboe Land; 5: north-east Wulff Land; 11: west side Navarana Fjord; 13: east side J. P. Koch Fjord; 16 \& 17: Kap Holger Danske. L.C.: Lower Cambrian; M.C.: Middle Cambrian; Tr.: Tremadoc; Ar.: Arenig; Llv.: Llanvirn; Ca.: Caradoc; As.: Ashgill; Ll.: Upper Llandovery.

omite (dolomite mudstone) which often shows grading on a scale of $1 \mathrm{~cm}$ or less. Sequences of $0.5-1.0 \mathrm{~m}$ thick graded beds and interbedded yellow dolomite and grey limestone (the 'tiger limestone' of Dawes, 1976) are also conspicuous. The majority of the breccia beds in Nyeboe Land are intraformational breccias derived by disruption of the tiger limestones. Further east many of the breccia/conglomerate beds are polymict with a variety of rounded or rectangular limestone and dolomite clasts, and often with a sandy matrix. A Middle Cambrian trilobite fauna was collected from this member in Nyeboe Land in 1966 by P. R. Dawes (Poulsen, 1969). In 1984 a trilobite collection was made from a level $82 \mathrm{~m}$ above the base of the starved basin sequence east of inner J. P. Koch Fjord (fig. 2, section 13), and has proved to be Middle Cambrian in age (J. S. Peel, personal communication, 1984). Llanvirn graptolites were collected at the top of the dolomitic unit west of Navarana Fjord; however, the upper boundary of this unit seems to be diachronous, possibly because of irregular secondary chertification.

The upper chert member comprises largely cherts and cherty shales, with partly chertified sequences of siltstone, black limestone and black dolomite. Rich graptolite collections have been made throughout the upper chert unit. Preliminary identifications of about $50 \mathrm{col}$ lections from ten measured sections by M. Bjerreskov (personal communication, 1984) show 
that the Ordovician is well represented by graptolites from the basal Arenig, basal Llanvirn and basal Caradoc, with smaller collections from the Tremadoc and lower Ashgill. No collections have as yet given Llandeilo or upper Ashgill ages. Collections from the top few metres of the chert unit in Nyeboe Land (fig. 2, section 3) and in Navarana Fjord (fig. 2, section 11; F. G. Christensen, personal communication, 1985) have yielded upper Llandovery ages, but lower and middle Llandovery graptolites have not yet been recovered. The upper chert unit thus seems to represent the whole of the Ordovician and the lower part of the Silurian, and is therefore broadly equivalent to the Amundsen Land Group of northern Peary Land (Friderichsen et al., 1982).

\section{Relationships with the Vølvedal Group and Amundsen Land Group}

At Kap Holger Danske, the west cape of Amundsen Land, two partial sections totalling $600 \mathrm{~m}$ for the entire sequence were measured (fig. 2 ; sections $16 \& 17$ ). Parts of the sequence here resemble the starved basin sequence to the west (described above), while other parts can be correlated with formations of the Vølvedal and Amundsen Land Groups (see Friderichsen et al., 1982).

The lowest $50 \mathrm{~m}$ includes cherty shales, two massive limestone breccia beds, thin limestones, and thick beds of channelled sandstone turbidites; the sandstone turbidites, not known in sequences to the west, are presumed to correlate with part of the Vølvedal Group. The following $150 \mathrm{~m}$ comprises largely laminated dolomites and dolomite mudstones, with a $15 \mathrm{~m}$ shale and chert unit in the middle and a $40 \mathrm{~m}$ calcareous shale unit with thin calcareous sandstone turbidites at the top; the dolomites and dolomitic mudstones largely correspond to the dolomite unit of sequences to the west, but correlation of the shale/chert unit within it is uncertain (fig. 2). The next part of the section comprises largely sandstone turbidites which can be correlated with the Vølvedal Group, while the uppermost unit of cherts and cherty shales is referred to the Amundsen Land Group (Friderichsen et al., 1982).

The thick sequence of dolomites and dolomite mudstones in the Kap Holger Danske section thins rapidly eastwards, but appears to be represented by a 10-20 m unit of dolomites towards the base of the Vølvedal Group at several localities farther east (writers' observations). The sandstone turbidites of the Vølvedal Group thin rapidly west of Kap Holger Danske and the last remnant is seen at Kap Bopa; they are interpreted as the western edge of a turbidite fan system which extended across northern Peary Land.

\section{Base of the Peary Land Group}

The top of the starved basin sequence interdigitates with the base of the turbidite sequence of the Silurian Peary Land Group. At several localities in Nyeboe Land, sections have been measured across the contact where a first unit of 5-10 m of typical, yellow weathering calcareous turbidites (Peary Land Group) is followed by a sequence of 5-20 m of dolomites and shales, to be succeeded in turn by the main sequence of Silurian turbidites (fig. 3; sections 1 \& 4). East of Nyeboe Land the contact with the Peary Land Group is most often sharp and conformable (fig. 3; sections $8 \& 11$ ), but may be marked by a transitional sequence of $10-20 \mathrm{~m}$ of siltstones (fig. 3; sections $6,9,17$ ).

Graptolite assemblages have been obtained from the basal few metres of the Peary Land Group at six localities between Kap Bopa and Nyeboe Land. Preliminary identifications (M. 

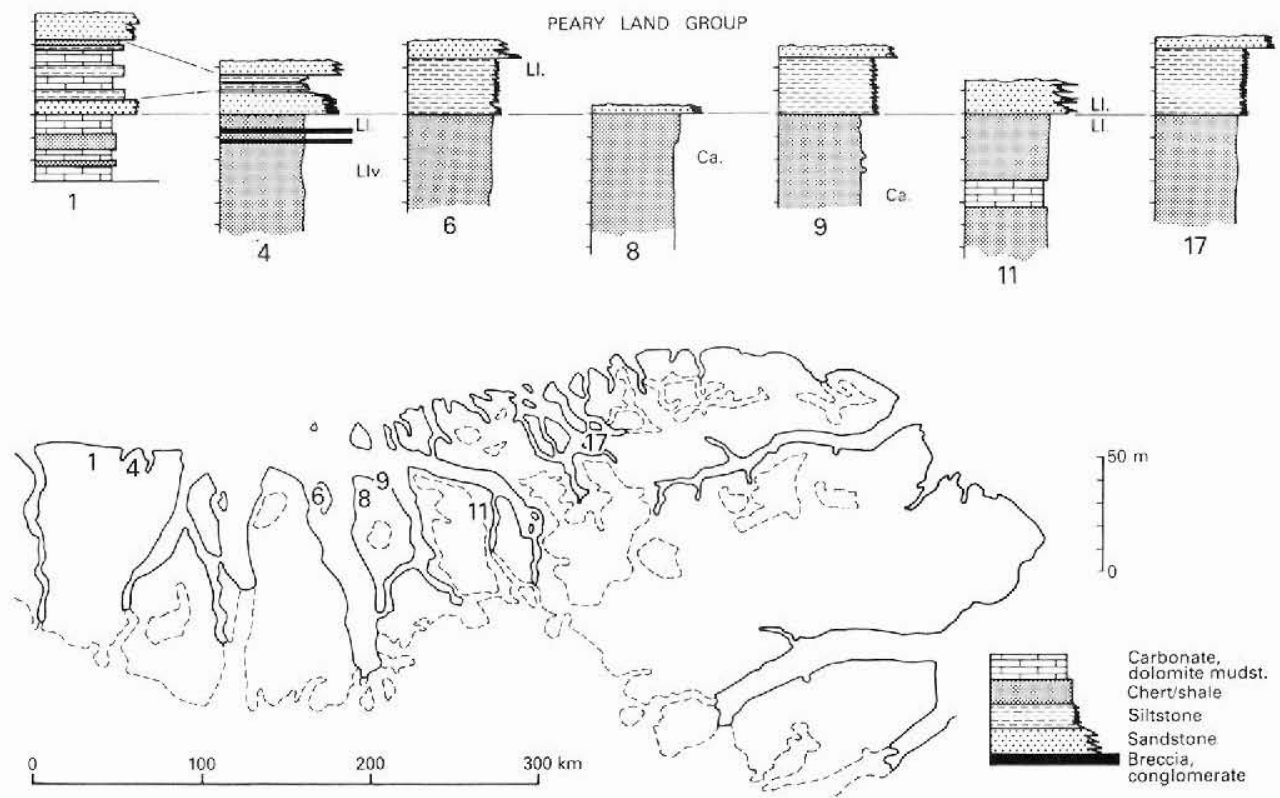

Fig. 3. Simplified measured sections across the contact between the starved basin sequence (mainly chert and shale) and the Peary Land Group (siltstone and sandstone turbidites). Sections 1 \& 4: north Nyeboe Land; 6: west Stephenson $\emptyset ; 8$ \& 9: north Nares Land; 11: west side Navarana Fjord; 17: Kap Holger Danske. Llv.: Llanvirn; Ca.: Caradoc; Ll.: Upper Llandovery.

Bjerreskov, personal communication, 1984) suggest that the base of the Peary Land Group is synchronous throughout this region in the early Upper Llandovery (fig. 3).

\section{References}

Christie, R. L. \& Ineson, J. R. 1979: Precambrian-Silurian geology of the G. B. Schley Fjord region, eastern Peary Land, North Greenland. Rapp. Grønlands geol. Unders. 88, 63-71.

Dawes, P. R. 1976: Precambrian to Tertiary of northern Greenland. In Escher, A. \& Watt, W. S. (edit.) Geology of Greenland, 248-303. Copenhagen: Geol. Surv. Greenland.

Dawes, P. R. 1982: The Nyeboe Land fault zone: a major dislocation on the Greenland coast along northern Nares Strait. In Dawes, P. R. \& Kerr, J. W. (edit.) Nares Strait and the drift of Greenland: a conflict in plate tectonics. Meddr Gronland, Geosci. 8, 177-192.

Dawes, P. R. \& Peel, J. S. 1984: Biostratigraphic reconnaissance in the Lower Palaeozoic of western North Greenland. Rapp. Grønlands geol. Unders. 121, 19-51.

Friderichsen, J. D. \& Bengaard, H. J. 1985: The North Greenland fold belt in eastern Nansen Land. Rapp. Grønlands geol. Unders. 126, 69-78.

Friderichsen, J. D., Higgins, A. K., Hurst, J. M., Pedersen, S. A. S., Soper, N. J. \& Surlyk, F. 1982: Lithostratigraphic framework of the Upper Proterozoic and Lower Palaeozoic deep water clastic deposits of North Greenland. Rapp. Grønlands geol. Unders. 107, 19 pp. 
Larsen, P.-H. \& Escher, J. C. 1985: The Silurian turbidite sequence of the Peary Land Group between Newman Bugt and Victoria Fjord, western North Greenland. Rapp. Grønlands geol. Unders. 126.

Peel, J. S. 1974: Lower Cambrian fossils from Nyeboe Land, North Greenland fold belt. Rapp. Grønlands geol. Unders. 65, 17 only.

Peel, J. S. 1979: Serrodiscus from northern Nyeboe Land, North Greenland. Rapp. Grønlands geol. Unders, 91, 116 only.

Peel, J. S. 1982: The Lower Paleozoic of Greenland. In Embrey, A. F. \& Balkwill, H. R. (edit.) Arctic geology and geophysics. Mem. Can. Soc. Petrol. Geol. 8, 309-330.

Peel, J. S. \& Larsen, N. H. 1984: Hadimopanella apicata from the Lower Cambrian of western North Greenland. Rapp. Grønlands geol. Unders. 121, 89-96.

Poulsen, V. 1969: An Atlantic Middle Cambrian fauna from North Greenland. Lethaia 2, 1-14.

Robson, M. J. 1983: A Lower Cambrian age for the Kennedy Channel Formation and Ella Bay Formation, Northeastern Ellesmere Island. Unpublished B.Sc. thesis, Laurentian Univ., Sudbury, Ontario. $17 \mathrm{pp}$.

Soper, N. J. \& Higgins, A. K. 1985: Thin-skinned structures at the basin-shelf transition in North Greenland. Rapp. Grønlands geol. Unders. 126, 87-94.

Surlyk, F. \& Hurst, J. M. 1984: The evolution of the early Paleozoic deep-water basin of North Greenland. Bull. geol. Soc. Am. 95, 131-154.

Surlyk, F., Hurst, J. M. \& Bjerreskov, M. 1980: First age-diagnostic fossils from the central part of the North Greenland fold belt. Nature 26, 800-803.

Trettin, H. P. 1971: Geology of lower Paleozoic formations, Hazen Plateau and southern Grant Land Mountains, Ellesmere Island, Arctic Archipelago. Bull. geol. Surv. Canada 203, 134 pp.

Trettin, H. P., Barnes, C. R., Kerr, J. W., Norford, B. S., Pedder, A. E. H., Riva, J., Tipnis, R. S. \& Uyeno, T. T. 1979: Progress in lower Paleozoic stratigraphy, northern Ellesmere Island, District of Franklin. Pap. geol. Surv. Canada 79-1B, 269-279. 